\title{
PENGGUNAAN ETIKA JURNALISTIK PADA PROGRAM ACARA DI TELEVISI (Studi Evaluatif Pada Program Reportase Investigasi TransTV Episode "Ayam Kampus")
}

\author{
Dwi Maharani \\ Universitas Bina Darma \\ email : dwimaharani2@yahoo.co.id
}

\begin{abstract}
Research entitled Implementation of Journalistic Ethics in Television Program Evaluative (Journalistic Evaluative Study On Impression Reporting Episode Investigation "Ayam Kampus") The problem formulation is how to depict the application of journalistic ethics in the program of Reportage Investigation in TRANS TV episode "Ayam kampus". used in this study is a qualitative method by using visual materials and interviews to analyze the data Analysis of data used by researchers based on journalistic ethics and in addition also through communication ethics Based on the results of research conducted it can be concluded that there are many parts based on journalistic ethics judging from the journalistic code of ethics on TRansTV Investigation Reports.
\end{abstract}

Keywords:Ethics of Journalism, Impressions, “ayam kampus”.

Abstrak : Penelitian berjudul Penerapan Etika Jurnalistik Dalam Program Acara Televisi (Studi Evaluatif Jurnalistik Pada Tayangan Reportase Investigasi Episode "Ayam Kampus"). Rumusan masalahnya aadalah; Bagaimana gambaran penerapan etika jurnalistik dalam program acara Reportase Investigasi di TRANS TV episode "Ayam Kampus". Metode yang digunakan dalam penelitian ini adalah metode Kualitatif dengan menggunakan bahan visual dan wawancara untuk menganalisis data. Analisis data yang digunakan peneliti berpedoman pada etika jurnalistik dan sebagai tambahan juga melalui etika komunikasi. Berdasarkan hasil penelitian yang dilakukan dapat disimpulkan bahwa sudah banyak bagian yang berpedoman pada etika jurnalistik dilihat dari kode etik jurnalistik pada tayangan Reportase Investigasi TRansTV.

Kata kunci:Etika Jurnalistik, Tayangan, Promosi, "Ayan Kamous"

\section{PENDAHULUAN}

Kemajuan dunia teknologi dan informasi terasa begitu cepat mengalami perubahan. Perubahan yang sangat terasa saat ini adalah perubahan dibidang teknologi komunikasi. Selama dua darsawarsa terakhir perkembangan teknologi komunikasi sudah sangat pesat, di dunia pada umumnya dan di Indonesia khususnya. Sekarang, ditengah perkembangan teknologi komunikasi semakin hari semakin canggih, masyarakat dapat dengan mudah menikmati beragam suguhan informasi dan hiburan dari berbagai media baik cetak maupun elektronik
Salah satu bentuk media massa elektronik yang sudah sangat dikenal masyarakat adalah televisi. Televisi merupakan salah satu media informasi yang jangkauannya bersifat massal, memiliki sirkulasi yang luas, dan dengan mudah diterima oleh seluruh lapisan masyarakat. Keunggulan televisi yang menyajikan audio dan video juga membantu seorang jurnalis saat melakukan laporan investigasi. Pembuktian sebuah perkara bisa dilakukan dengan menyajikan video dan audio tersembunyi kesaksian dari pelaku. 
Pada awalnya laporan investigasi memaparkan data dengan diperkuat bukti berupa foto lalu dianalisis oleh seorang jurnalis secara mendalam dalam sebuah surat kabar atau majalah. Namun, kemunculan media-media baru dalam pemberitaan membuat jurnalis memodifikasi laporan investigasi yang ada. Penonton saat ini dapat menyaksikan sebuah laporan investigasi lengkap beserta gambar gerak dan suara (video dan audio). Hal tersebut tentunya memenuhi rasa ingin tahu penonton secara detail sebuah kejadian. Bukti-bukti video dan audio tersebut membuat penonton lebih percaya sekalipun sebenarnya masih bisa direkayasa.

Menurut Boyd dalam (Santana, 2009: 237) jurnalisme investigatif memang berbeda dengan kegiatan jurnalistik pada umumnya. Terminologi investigative journalism (jurnalisme investigatif) memberikan atribut penyelidikan, keingintahuan dan misi tertentu dari para wartawannya.Wartawan investigasi tidak bekerja berdasarkan pengagendaan berita seperti yang dalam peliputan reguler melainkan memasuki subjek pemberitaan tatkala mereka tertarik untuk mengetahui sesuatu.

Seperti halnya tayangan Reportase Investigasi di TRANS TV yang menayangkan produk jurnalisme investigasi. Sebagai contoh, penayangan Reportase Investigasi tentang kejahatan perkawinan yang dilakukan pejabat publik. Data komnas perempuan sepanjang tahun 2012 menunjukan ada 102 (Seratus Dua) kasus kejahatan perkawinan yang dilakukan oleh pejabat publik. Sebagian kasus tersebut adalah tentang gratifikasi seks atau perempuan mudah yang dijadikan simpanan para pejabat dan di antaranya juga melibatkan mahasiswi yang memiliki profesi ganda yang biasa disebut dengan istilah ayam kampus. (Tayangan Reportase Investigasi episode "Ayam Kampus", ditayangkan TRANS TV pada tanggal 15 juni 2013 hari Sabtu pukul 16.00 WIB).

Kebenaran yang dipaparkan wartawan investigasi tersebut bisa saja menimbulkan efek yang berbeda pada penayangannya karena menyangkut norma dan etika. Jurnalis investigasi tidak bisa dinilai hanya berdasarkan teknik dalam menyampaikan informasi, melainkan ada etika yang seharusnya berada dibelakang jurnalis tersebut. Oleh karena itu dalam setiap aktivitasnya, baik jurnalis pada umumnya maupun jurnalis investigasi, wajib menjunjung tinggi profesinya dengan mengikuti kaidah norma dan etika profesi yang mengaturnya.

Darji Darmodiharjo dan Shidarta dalam Mufid (2010: 173) sifat dasar etika adalah sifat kritis, karenanya etika bertugas untuk mempersoalkan norma yang dianggap berlaku. Diselidikinya apakah dasar suatu norma itu dan apakah dasar itu membenarkan ketaatan yang dituntut oleh norma itu terhadap norma yang dapat berlaku. Etika sendiri menjadi alat pemikiran yang rasional dan bertanggung jawab bagi seorang ahli dan bagi siapa saja yang tidak mau diombang-ambingkan oleh norma-norma yang ada.

Oleh karena itu etika menjadi pegangan pokok oleh jurnalis karena dipandang sebagai sarana orientasi bagi manusia untuk menjawab suatu pertanyaan fundamental. Etika membantu jurnalis dalam mencari nilai dan orientasi menyangkut tujuan dan pilihan tindakan agar jurnalis dapat mengerti setiap keputusan tindakan yang diambil dan mampu bertanggung 
jawab terhadap keputusan itu. Kemandirian menentukan pilihan, bukan hanya mengikuti keputusan orang lain.

Peneliti menilai penelitian tentang etika sangat penting untuk melakukan evaluasi terhadap apa yang dilakukan oleh media selama ini terutama pada kegiatan jurnalisme investigasi. Apakah media massa saat ini telah menggunakan kaidah-kaidah yang benar dalam peliputan jurnalisme investigasi, atau ternyata belum sama sekali.

Peneliti memilih program acara Reportase Investigasi yang ditayangkan oleh Trans TV episode "ayam kampus" karena program ini bisa dibilang salah satu program yang sukses pada tayangan laporan investigasi dan program ini pernah masuk dalam penghargaan KPI awards 2010.

\section{METODOLOGI PENELITIAN}

\subsection{Metode Penelitian}

Penelitian kualitatif menurut Moleong adalah penelitian yang bermaksud untuk memahami fenomena tentang apa yang dialami oleh obyek penelitian misalnya perilaku, persepsi, motivasi, tindakan, dan lain-lain, secara holistis atau meyeluruh, dan dengan cara evaluatif (Moleong, 2008:8).

Penelitian ini bisa dimasukkan dalam jenis penelitian kualitatif dilihat dari penelitian yang dilakukan secara menyeluruh terhadap pertimbangan etika jurnalis berkaitan dengan pilihan dan orientasi tindakan yang diambil jurnalis investigasi pada acara Reportase Investigasi di Trans TV dengan melihat teks pada episode "Ayam Kampus". Episode tersebut akan dianalisis dengan menggunakan tahap-tahap yang ada dari pasal-pasal kode etik jurnalistik dan sebagai tambahan menggunakan Potter Box.

Potter Box merupakan kotak yang melihat pertimbangan etis seseorang dalam menentukan keputusan.Potter Box cocok digunakan dalam penelitian ini karena penelitian ini hendak melihat pertimbangan-pertimbangan moral yang diambil jurnalis dalam memustuskan bagaimana mereka melakukan liputan investigasi.

\subsection{Studi Evaluatif}

Penelitian evaluatif adalah suatu penelitian persyaratan yang harus dipenuhi, yaitu adanya kriteria, tolak ukur, atau standar yang digunakan sebagai pembanding bagi data yang diperoleh dan menguji pelaksanaan suatu program, (Arikunto, 2010:36).

Secara terperinci tujuan penelitian evaluatif adalah sebagai berikut:

1) Membantu perencanaan pelaksanaan program.

2) Membantu dalam penentuan keputusan penyempurnaan atau perubahan program.

3) Membantu dalam penentuan keputusan keberlanjutan atau penghentian program.

4) Menemukan fakta-fakta dukungan atau penolakan terhadap program, dan

5) Memberikan sumbangan dalam pemahaman proses psikologis, sosial dan politik dalam pelaksanaan program serta faktor yang mempengaruhi. Jadi tujuan utama dari penelitian evaluatif adalah sebagai penyedia informasi berkaitan 
dengan program-program pendidikan yang telah dilaksanakan.

\subsection{Metode Analisis}

Peneliti menganalisis permasalahan dengan melalui kode etik jurnalistik dan sebagai tambahan melalui analisis Potter Box. Potter Box membantu kita untuk melakukan uji konsistensi sehingga keputusan kita dapat dipertanggungjawabkan.

Peneliti melihat keempat bagian kotak Potter (Potter Box) cocok dalam menghadapi argumentasi moral.Empat bagian kotak itu merupakan tahap-tahap yang harus dilalui peneliti dalam melakukan penelitian ini.Empat langkah untuk menemukan juga menganalisis keputusankeputusan etis tersebut digunakan dalam bagan yang diadaptasi dari buku Patterson (2008: 100) berikut ini.

What Actually happens? What ought tohappen?

\begin{tabular}{|c|c|}
\hline Facts & Loyalties \\
\hline Values & Principles \\
\hline
\end{tabular}

Gambar 3.1 Bagan empat langkah Potter Box

Sumber: Patterson, 2008

Bagan tersebut menunjukan langkahlangkah analisis dengan menggunakan Potter Box. Keterangan "what actually happens?" artinya bahwa pada tahap analisis fakta dan nilai, peneliti melihat tayangan yang ada menggambarkan kondisi seperti apa? Sedangkan keterangan "what ought to happen?" artinya bahwa pada tahap prinsip dan loyalitas peneliti memaparkan apa yang seharusnya terjadi.

\section{Facts/Fakta}

Understanding The Fact of the case atau mengindentifikasi realitas empiris yang ada dalam sebuah kasus.Fakta yang ada diidentifikasi sedetil mungkin (Patterson, 2008: 101).

Pada tahap ini fakta diidentifikasi.Faktafakta yang ada di teks dikonfirmasikan kebenarannya dengan fakta-fakta yang didapat melaui wawancara. Hal tersebut akan membuat data yang ada di dalam teks lebih valid.

\section{Value/Nilai}

Outlining the values inherent in the decision atau nilai-nilai ideal yang akan diambil di dalam keputusan. Identifikasi pada tahap ini berupa identifikasi atas nilai-nilai yang ideal subyek sesuai kapasitas profesinya dan mengevaluasi atas pencapaian nilai-nilai ideal tersebut (Patterson, 2008: 101).

Seperti yang sudah dijelaskan pada bagian metode pengumpulan data, wawancara selain digunakan untuk mengkonfirmasi data, juga digunakan untuk melihat alasan-alasan dari keputusan kontroversial yang dilakukan. Dari wawancara tersebut dapat dilihat juga bagaimana proses peliputan dan nilai-nilai apa yang dipertahankan.

\section{Principles/Prinsip}

Tahap ini peneliti mengidentifikasi prinsip-prinsip etika bermedia yang relevan dengan pencapaian tindakan subyek atas nilainilai ideal yang dianut subjek. Prinsip-prinsip etika tersebut terdiri atas Hedonisme, Eudonisme, Utilitarian, Deontologi (Patterson, 2008: 101).

\section{Loyalties}


Pada tahap keempat ini loyalitas jurnalis atas tindakannya diidentifikasi. Kepada siapakah editor memiliki kesetiaan?Di dalam bukunya Fink menjabarkan ada empat loyalitas seperti di bawah ini (Fink, 1995: 18).

a. Self and conscience diri sendiri dan suara hati.

b. Loyality to society. Loyalitas kepada masyarakat.

c. Loyality to the hand that feeds you. Loyalitas terhadap kepentingan tertinggi yang memberi mereka makan.

d. Loyality to professional peers. Loyalitas kepada sesama profesi jurnalis sebagai pekerja profesional.

\subsection{Subyek dan Objek Penelitian}

Subyek dalam penelitian ini adalah tim Reportase Investigasi. Peneliti berpendapat bahwa yang tahu tentang pertimbangan alasan melakukan keputusan kontroversial tidak lain adalah pelaku kegiatan jurnalistik itu sendiri.

Sedangkan Obyek penelitian dalam penelitian ini adalah teks tayangan dan alasan tayangan-tayangan tim Reportase Investigasi dalam mengambil keputusan.

\section{HASIL}

\subsection{Analisis Etika Jurnalistik Reportase Investigasi Trans TV}

Etika jurnalistik adalah ketentuan bagaimana seorang wartawan menyampaikan suatu berita, yaitu berita yang memenuhi standar jurnalistik profesional, seperti memisahkan opini, mengungkapkan fakta dan kutipan secara akurat, tidak emosional dan sensational, seimbang dan adil, berupaya selalu dalam kerangka cover both side, serta selalu menempatkan dan mempertimbangkan kepentingan publik (Dewan Pers, 2003:9).

Dalam penelitian ini, peneliti menganalisis bagaiamana gambaran penerapan etika jurnalistik dalam program acara Reportase Investigasi episode "ayam kampus" dilihat melalui pasal-pasal dalam kode etik jurnalistik yang ada dan sebagai tambahan dibandingkan melalui etika komunikasi apakah program acara Reportase Investigasi TRANS TV telah berpedoman pada etika? Lebih jelasnya dapat dilihat bagian bentuk scene, audio dan keterangan audio dan video tayangan reportase investigasi sebagai berikut:

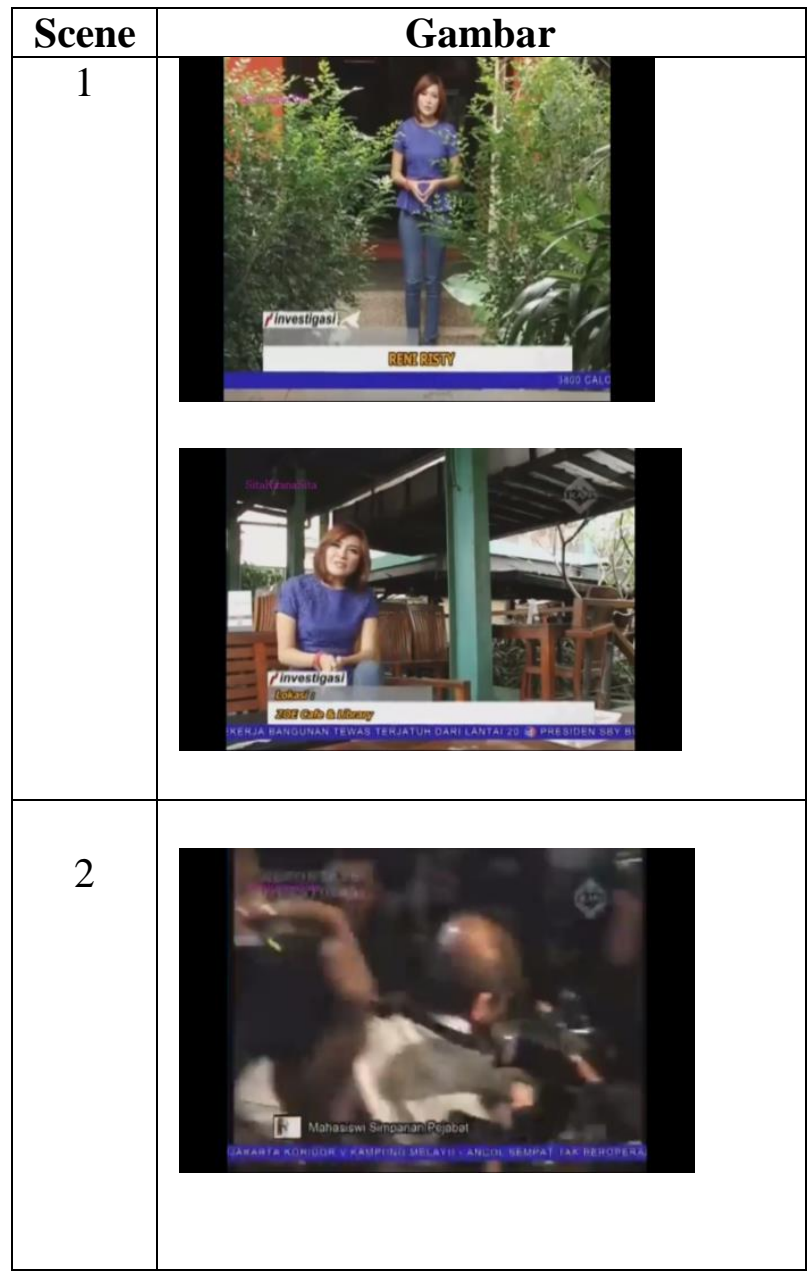



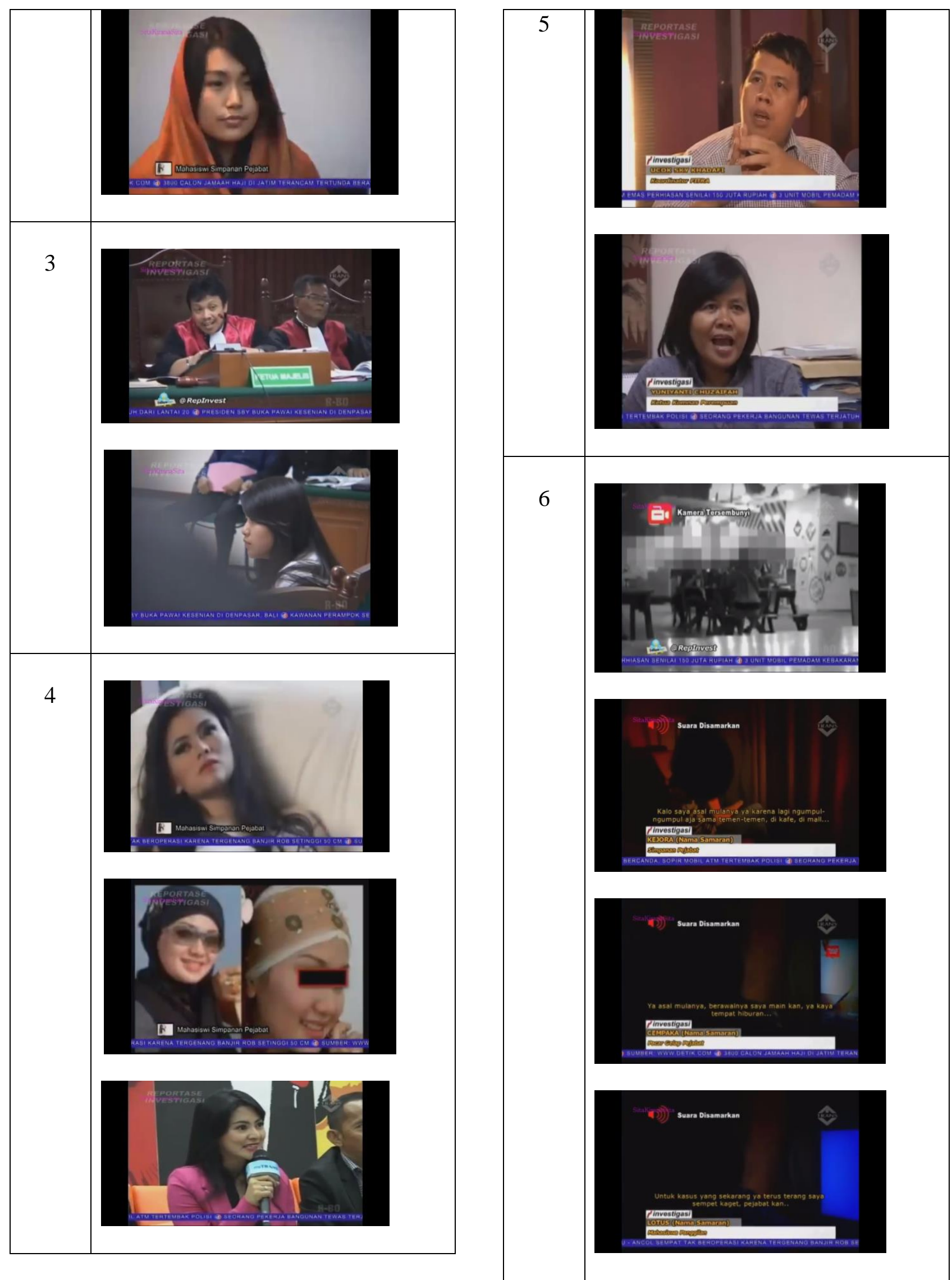


\section{Gambar 3.1 Scene Dalam Tayangan Reportase Investigasi episode "Ayam Kampus"}

Berikut ini adalah transkrip yang ada pada video tayangan Reportasi Investigasi episode "Ayam Kampus":

Tabel 3.1 Transkrip dan Penjelasan Scene Dalam Tayangan Reportase Investigasi episode "Ayam Kampus"

\begin{tabular}{|l|l|}
\hline \multicolumn{1}{|c|}{ Transkrip Audio } & \multicolumn{1}{|c|}{ Penjelasan } \\
\hline & \\
Pengantar dari Reni Risty & Scene 1: \\
(Host) : Data komnas & Scene 1 \\
perempuan sepanjang Tahun & merupakan \\
2012 menunjukan ada 102 & pengantar dari \\
kasuskejahatan & Reni Risty \\
perkawinanyang dilakukan & (Host) \\
oleh pejabat publik. Sebagian & pembawa \\
kasus adalahtentang & acara \\
gratifikasi seks atau & Reportase \\
perempuan mudah yang & investigasi \\
dijadikan simpanan para & episode "ayam \\
pejabat. & kampus" \\
& \\
Pada reportase investigasi kali & \\
ini kami menemui beberapa & \\
perempuan yang di jadikan & \\
simpanan ataugratifikasi seks & \\
\hline
\end{tabular}

Pada 29 januari 2013 komisi pemberantas korupsi (KPK) menangkap Ahmad Fatonah pengusaha yang dekat dengan Lutfi Hasan Ishak mantan Presiden partai keadilan sejahtera (PKS). Ahmad Fatonah di tangkap di sebuah kamar hotel bersama seorang perempuan muda Maharani Sujiono yang merupakan mahasiswi sebuah perguruan tinggi. Pria asal sulawesi selatan ini di copot KPK karena diduga terlibat dalam kasus suap sapi impor. Namun perkembangan kasus tidak hanya bergulir pada dugaan korupsi peran maharani sujiono justru menyita perhatian lebih banyak.

"Jaksa : Seperti yang sudah di jelaskan bahwa benar tidak anda mempunyai hubungan intim

"Maharani : iya uang kaitannya dengan ajakan Maharani : iya
Jaksa : trus anda itu berikan

Scene 2:

Scene 2

Merupakan pembertitaan penangkapan Ahmad Fatonah dalam sebuah kamar hotel bersama seorang perempuan muda Maharani Sujiono.

Scene 3:

Scene 3 adalah sidang pengakuan Maharani Sujiono tentang fakta dirinya di bayar Fatonah untuk berhubungan intim dengan bayaran 10 juta rupiah.

maharani bukan satu-satunya perempuan yang menerima uang dari Fatonah. Di duga ada 45 perempuan lainnya yang menerima uang melalui transfer bank

salah satunya model majalah pria dewasa Vithalia Sehsa "Vithalia Sehsa : Ya ampun.. ya Allah ne malaikat baik banget gitu kan ngasihnya sampe, belum kenal aja udah ngasih ini itu gitu.

\section{Scene 4:}

Scene 4

Scene 4 adalah perempuan perempuan cantik yang di duga menerima transfer uang dari Fatonah salah satunya Vithali Sehsa yang mengaku dirinya telah diberikan mobil sedan, arloji dan sejumlah uang 


\begin{tabular}{|l|l|}
\hline & besar \\
\hline Forum indonesia untuk & Scene 5: \\
transfaransi anggaran atau & Scene 5 adalah \\
fitrah menyebutkan fatonah & pendapat \\
harus dijerat dengan undang- & menurut Ucok \\
undang korupsi karena di duga & Sky Khadafi \\
terlibat dalam gratifikasi seks & (Koordinator \\
Ucok Sky Khadafi (Kordinator & fitra) dan \\
Fitra) : “jadi sebetulnya & Chuzaifah \\
Banyak aparat hukum kita & (Ketua \\
lepas terhadap gratifikasi seks \\
nya, meraka hanya melihat dari \\
sudut korupsinya saja, udah \\
itubarang buktinya hanya uang \\
yang di kasih kepada si wanita & Perempuan) \\
itu tapi mereka tidak melihat \\
apa maksudnya itu, & seks. \\
seharusmya dua-dua nya harus \\
terungkap".
\end{tabular}

\begin{tabular}{|c|c|}
\hline $\begin{array}{l}\text { berlanjut lewat telepon” } \\
\text { "mulai dari fasilitas biasa aja } \\
\text { sampai yang luar biasa. Ya jadi } \\
\text { di iming-imingi nanti aku } \\
\text { kassih tiket liburan deh ke bali, } \\
\text { singapura, ke malaysia deh" } \\
\text { " ya baru jadi simpanan } 2 \\
\text { orang, satu di Pemda, satu di } \\
\text { Pemprov" } \\
\text { "Cempaka : ya asal mulanya, } \\
\text { berawalnya saya main kan, ya } \\
\text { kaya tempat hiburan clubing, } \\
\text { dugem gitu, dari temen ke } \\
\text { temen sih, dari situ saya } \\
\text { dikenalin jadi kenal, seperti } \\
\text { itu,”" } \\
\text { " ya pengalaman saya jadi } \\
\text { cuman untuk melayani aja,,, } \\
\text { disuruh ya udah gitu kan, ya } \\
\text { biasalah ditawarin harga ya } \\
\text { udah gitu... pengusaha dia, } \\
\text { usaha-usaha ya kayak buka } \\
\text { mini market, banyak dia } \\
\text { pegangannya waktu itu” } \\
\text { "Lotus : untuk kasus yang } \\
\text { sekarang ya terus terang saya } \\
\text { sempet kaget, pejabat kan trus } \\
\text { ada kasus kayak gitu ya saya } \\
\text { kaget, saya takut, istilahnya } \\
\text { takut kebawa-bawa, } \\
\text { otomatisnya ya takut” }\end{array}$ & \begin{tabular}{|l} 
pejabat yang \\
dinamakan \\
ayam kampus
\end{tabular} \\
\hline
\end{tabular}

Sumber: Hasil Analisis Peneliti, 2014.

Berdasarkan scene diatas dapat dianalisis sebagai berikut:

1. Pada scene 1 merupakan pengantar dari Reni Risty (Host) pembawa acara Reportase investigasi episode "ayam kampus" .

"Data komnas perempuan sepanjang tahun 2012 menunjukan ada 102 kasuskejahatan perkawinanyang dilakukan oleh pejabat publik. Sebagian kasusadalahtentang gratifikasi seks atau perempuan mudahyang dijadikan simpanan para pejabat" 
Dilihat dari penerapan kode etik jurnalistik scene 1 sudah berpedoman pada etika jurnalistik sesuai pada pasal 2 yang berisi tentang wartawan Indonesia menempuh cara-cara yang profesional dalam melaksanakan tugas jurnalistik. Dilihat dari cara pengambilan gambarnya wartawan sudah profesional dalam pemilihan lokasi atau tempat yang sesuai dengan tema berita tentang ayam kampus dan pasal 4 yang berisi tentang wartawan Indonesia tidak membuat berita bohong, fitnah, sadis dan cabul karena dari pemaparan presenter sudah sesuai dengan fakta tentang kejahatan perkawinan yang dilakukan oleh pejabat publik dilihat dari data Komnas perempuan sepanjang tahun 2012.

Berdasarkan etika komunikasi scene 1 sudah memenuhi kriteria dari fakta, nilai, prinsip dan loyalitas (Patterson,2008: 100).

2. Scene 2 merupakan pemberitaan penangkapan Ahmad Fatonah dalam sebuah kamar hotel bersama seorang perempuan muda Maharani Sujiono.

"Pada 29 januari 2013 komisi pemberantas korupsi (KPK) menangkap Ahmad Fatonah pengusaha yang dekat dengan Lutfi Hasan Ishak mantan Presiden partai keadilan sejahtera (PKS). Ahmad Fatonah di tangkap di sebuah kamar hotel bersama seorang perempuan muda Maharani Sujiono yang merupakan mahasiswi sebuah perguruan tinggi. Pria asal sulawesi selatan ini dicopot KPK karena diduga terlibat dalam kasus suap sapi impor. Namun perkembangan kasus tidak hanya bergulir pada dugaan korupsi peran Maharani Sujiono justru menyita perhatian lebih banyak".

Dilihat dari penerapan kode etik jurnalistik scene 2 sudah berpedoman pada etika jurnalistik sesuai pada pasal 4 yang berisi tentang wartawan
Indonesia tidak membuat berita bohong, fitnah, sadis dan cabul karena sesuai dengan fakta berita yang benar-benar terjadi pada tanggal 29 Januari 2013 tentang penangkapan Fatonah di sebuah kamar hotel bersama seorang perempuan muda Maharani Sujiono.

Berdasarkan etika komunikasi scene 2 sudah memenuhi kriteria dari fakta, nilai, prinsip dan loyalitas.

3. Scene 3 adalah sidang pengakuan Maharani Sujiono tentang fakta dirinya di bayar Fatonah untuk berhubungan intim dengan bayaran 10 juta rupiah.

“Jaksa : Seperti yang sudah di jelaskan bahwa benar tidak anda mempunyai hubungan intim

"Maharani : iya

Jaksa : trus anda itu berikan uang kaitannya dengan ajakan

Maharani : iya

Dilihat dari penerapan kode etik jurnalistik video 3 sudah berpedoman pada etika jurnalistik sesuai pada pasal 1 yang berisi tentang wartawan Indonesia bersikap independen, menghasilkan berita yang akurat, berimbang dan tidak beritikad buruk karena sesuai pengakuan Maharani Sujiono di pengadilan serta pada pasal 4 yang berisi tentang wartawan Indonesia tidak membuat berita bohong, fitnah, sadis dan cabul karena telah sesuai dengan fakta yang dilihat dari percakapan jaksa dan Maharani Sujiono. Berdasarkan etika komunikasi scene 3 sudah memenuhi kriteria dari fakta, nilai, prinsip dan loyalitas.

4. Scene 4 adalah perempuan-perempuan cantik yang di duga menerima transfer uang dari Fatonah salah satunya Vithali Sehsa 
yang mengaku dirinya telah diberikan mobil

sedan, arloji dan sejumlah uang besar.

Maharani bukan satu-satunya perempuan yang menerima uang dari Fatonah. Di duga ada 45 perempuan lainnya yang menerima uang melalui transfer bank salah satunya model majalah pria dewasa Vithalia Sehsa

“Vithalia Sehsa : Ya ampun.. ya Allah ne malaikat baik banget gitu kan ngasihnya sampe, belum kenal aja udah ngasih ini itu gitu"

Dilihat dari penerapan kode etik jurnalistik Scene 4 sudah berpedoman pada etika jurnalistik sesuai pada pasal 2 yang berisi tentang wartawan Indonesia menempuh cara-cara yang profeional dalam melaksanakan tugas jurnalistik karena disini untuk mendapatkan berita yang akurat wartawan langsung mewawancara atau jumpa pers dengan Vithalia Sehsa dan pasal 3 wartawan Indonesia selalu menguji informasi, memberitakan secara berimbang, tidak mencampurkan fakta dan opini yang menghakimi, serta menerapkan asas praduga tak bersalah karena disini masih ada dugaan sementara bahwa masih ada 45 wanita lainnya yang menerima uang melalui transfer bank dan dari segi pengambilan scene wartawan tidak mengambil foto Vithalia secara full karena mengandung konten dewasa selain itu wartawan juga sudah berpedoman pada pasal 5, pasal 7 dan pasal 9 melindungi identitas salah satu perempuan cantik yang diduga menerima uang melalui transfer bank. Berdasarkan etika komunikasi scene 4 sudah memenuhi kriteria dari fakta, nilai, prinsip dan loyalitas.

5. Scene 5 adalah pendapat menurut Ucok Sky Khadafi (Koordinator Fitra) dan Yuninanti
Chuzaifah (Ketua Komnas Perempuan) tentang gratifikasi seks.

Forum indonesia untuk transfaransi anggaran atau fitrah menyebutkan fatonah harus dijerat dengan undang-undang korupsi karena di duga terlibat dalam gratifikasi seks.

Ucok Sky Khadafi (Kordinator Fitra) : “ jadi sebetulnya Banyak aparat hukum kita lepas terhadap gratifikasi seks nya, meraka hanya melihat dari sudut korupsinya saja, udah itubarang buktinya hanya uang yang di kasih kepada si wanita itu tapi mereka tidak melihat apa maksudnya itu, seharusmya dua-dua nya harus terungkap".

Yuninanti Chuzaifah (Ketua
Perempuan): "Kitar sedang
mengidentifikasi berbagai jenis
kekerasan seksual, gratifikasi seksual ini
ada dimensi soal eksploitasi seksual jadi
ini termasuk kekerasan perempuan yang
harus dipidana tetapi berapa tahunnya
dan bagaimana prinsip menjerahkannya
itu yang harus didiskusikan lagi".

Dilihat dari penerapan kode etik jurnalistik scene 5 sudah berpedoman pada etika jurnalistik sesuai pada pasal 2 yang berisi tentang wartawan Indonesia menempuh caracara yang profesional dalam melaksanakan tugas jurnalistik. Dikatakan profesional karena wartawan disini mewawancari langsung narasumber untuk memperoleh data yang lebih akurat seperti yang terdapat pada pasal 1. Pasal 11 tentang wartawan Indonesia melayani hak jawab dan hak koreksi secara profesional. Berdasarkan etika komunikasi scene 5 sudah memenuhi kriteria dari fakta, nilai, prinsip dan loyalitas.

6. Scene 6 adalah penelusaran tim reportase investigasi di kafe-kafe dan pengakuan 
beberapa mahasiswi cantik yang namanya di samarkan yaitu kejora, cempaka, dan lotus. Mereka ini lah yang berprofesi ganda yang menjadi simpanan oknum-oknum pejabat yang dinamakan ayam kampus.

Data yang dimiliki komnas perempuan menjadi acuan kami dalam melakukan penelusuran di beberapa kafe untuk mencari informasi. Pencarian kami berujung pada seorang mahasiswi perempuan muda ini memiliki profesi ganda sebagai simpanan oknum pejabat pemerintah.

Nama perempuan itu kami samarkan bernama Kejora

"Kejora: kalo saya asal mulanyaya karena lagi ngumpul-ngumpul aja sama teman-teman di kafe, di mall lagi hapyhappy ajalah sama teman-teman, ya terus di ajak kenalan sama ajudan pejabatnya, terus ngobrol-ngobrol minta nomor telepon, berlanjut lewat telepon"

"Mulai dari fasilitas biasa aja sampai yang luar biasa. Ya jadi di iming-imingi nanti aku kasih tiket liburan deh ke Bali, Singapura, ke Malaysia deh"

"ya baru jadi simpanan 2 orang, satu di Pemda, satu di Pemprov"

"Cempaka: ya asal mulanya, berawalnya saya main kan, ya kaya tempat hiburan clubing, dugem gitu, dari temen ke temen sih, dari situ saya dikenalin jadi kenal, seperti itu,,"

"ya pengalaman saya jadi cuman untuk melayani aja,,, disuruh ya udah gitu kan, ya biasalah ditawarin harga ya udah gitu... pengusaha dia, usaha-usaha ya kayak bukamini market, banyak dia pegangannya waktu itu.

"Lotus: untuk kasus yang sekarang ya terus terang saya sempet kaget, pejabat kan trus ada kasus kayak gitu ya saya kaget, saya takut, istilahnya takut kebawa-bawa, otomatisnya ya takut"

Dilihat dari penerapan kode etik jurnalistikscene 6 sudah berpedoman pada etika jurnalistik dilihat dari pasal 3 yang berisi tentang wartawan Indonesia selalu menguji informasi, memberitakan secara berimbang, tidak mencampurkan fakta dan opini yang menghakimi serta menerapkan asas praduga tak bersalah karena wartawan melakukan penelusuran langsung ke beberapa cafe untuk mencari informasi berdasarkan acuan data komnas perempuan dan dari segi pengambilan gambar wartawan sudah berpedoman pada Pasal 2, pasal 5, pasal 7, pasal 9 karena terlihat pada scene gambar di buramkan yang berarti wartawan sangat profesional dalam menjalankan tugasnya.

Selain itu pada scene gambar wartawan juga menyamarkan nama dan suara asli narasumber yang dilihat dari pasal 5 tentang wartawan Indonesia tidak menyebutkan dan menyiarkan identitas korban kejahatan asusila dan tidak menyebutkan identitas pelaku kejahatan. Pasal 7 wartawan Indonesia memiliki hak tolak untuk melindungi narasumber yang tidak bersedia diketahui identitas maupun keeradaannya, menghargai ketentuan embargo, informasi latar belakang, dan "off the record" sesuai dengan kesepakatan. Pasal 9 wartawan Indonesia menghormati hak narasumber tentang kehidupan 
pribadinya, kecuali untuk kepentingan umum.Namun pengambilan berita pada narasumber yang dilakukan wartawan tidak sesuai dengan pasal 2 dimana wartawan tidak menempuh cara-cara yang profesional dalam melaksanakan tugas jurnalistik, karena disini wartawan membayar nasasumber atau pelaku kejahatan untuk memperoleh informasi.Tetapi ditinjau dari etika komunikasi itu sah-sah saja , dilihat dari fakta, nilai, loyalitas, dan prinsip (Patterson, 2008: 100).Fakta : Kebenaran atau peristiwa yang terjadi, Fakta yang diidentifikasi sedetil mungkin.Nilai : Nilai yang ada dalam diri setiap jurnalis, nilai tersebut antara lain Truth-telling (Kejujuran), Humanenees (Humanis), Stewardship (Pelayanan), Justice (Keadilan), dan Freedom (Kebebasan).Dalam pengambilan informasi jurnalis memiliki nilai kebebasan, yaitu melakukan segala upaya untuk tetap bebas dari berbagai macam asosiasi, ideologi, kelompok, atau orang yang mungkin membatasi kebebasan pers atau kebebasan pribadi mereka untuk meliputi berita karena harus ditutupi.Loyalitas : Pengertian jurnalis atas tindakannya.Prinsip : Prinsip-prinsip yang relevan dengan pencapaian tindakan subyek atas niainilai ideal yang dianut.

\subsection{Analisa Etika Jurnalistik} Reportase Investigasi Trans TV dari Sudut Pandang Perancang Investigasi

\section{Trans TV Dan KPI (Komisi Penyiaran Indonesia).}

Selain melalui media bahan visual peneliti juga menggunakan metode wawancara sebagai penunjang untuk memperkuat data dari hasil analisis ini. Peneliti berpendapat bahwa yang tahu tentang pertimbangan alasan melakukan keputusan kontroversial tidak lain adalah pelaku kegiatan jurnalistik itu sendiri.

Peneliti menghubungi mantan Kepala Departemen News Trans TV, Satrio Arismunandarpada 22Mei 2014. Jelas dalam hal ini Satrio sempat mengalami dinamika selama tayangan ini dibuat. Karena Satrio sudah bukan bagian dari sebuah perusahaan media maka peneliti menganggap informasi yang dia berikan tentunya akan lebih bebas atau terbuka daripada jurnalis yang masih memiliki ikatan kerja.

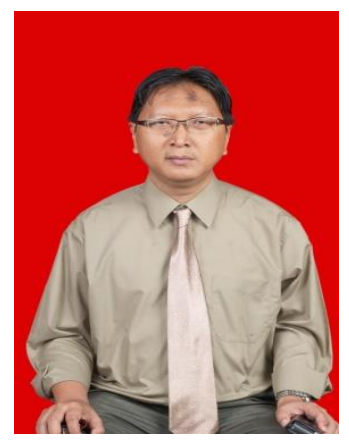

\section{Gambar 3.3 Foto Profil Informan Sumber: Trans TV}

$\begin{array}{ll}\text { Nama } & : \text { Satrio Arismunandar } \\ \text { Usia } & : \text { 53 Tahun } \\ \text { Pekerjaan } & \text { : Jurnalis }\end{array}$

\subsubsection{Kesulitan atau Tantangan}

\section{Memproduksi Reportase Investigasi}


Menurut Satrio Arismunandar

kesulitannya adalah mencapai topik yang pas (bisa dibuat dan tayangan tepat waktu, secara visual menarik, secara teknik mudah, resiko/ancaman terhadap keselamatan reporter bisa ditangani, tidak butuh biaya mahal, isunya baru dan unik). Yang sulit adalah melobi narasumber agar mau diwawancarai, itu bisa butuh waktu 2 minggu lebih.

\subsubsection{Perbedaan Reportase Investigasi Saat ini dan Proses Negosiasi dengan Pelaku Kriminalitas}

Menurut Satrio Arismunandar sama saja. Dalam proses negosiasi, negosiator harus memberi jaminan wajah dan suara mereka akan disamarkan (jaminan keamanan). Juga tentu ada honor yang harus dibayar (bisa nego soal besarnya bayaran).

\subsubsection{Teror atau Ancaman Memproduksi} Tayangan Reportase Investigasi

Menurut Satrio Arismunandar biasanya yang diancam bukan produser, tetapi si reporter, karena dia yang dikenal oleh narasumber atau pihak-pihak yang terlibat dan bertemu di lapangan. Ada yang diancam akan dipukul atau digebukin. Liputan berbahaya, biasanya negoasiator membawa satpam kantor Trans Tv (biasanya exTNI) untuk berjaga-jaga.

Selain Satrio Arismunandar peneliti juga mewawancarai Kemas Badaruddin koordinator bidang pegawasan isi siaran di KPI.

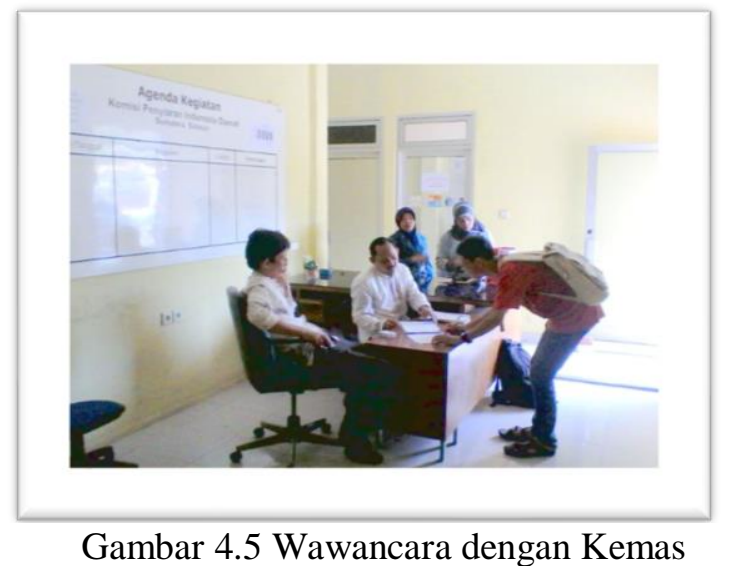

Sumber: Peneliti, 2014.

$$
\text { Badaruddin }
$$

Menurut Kemas Badaruddin bahwa penayangan reportase investigasi sudah memenuhi kriteria dari Pedoman, perilaku, penyiaran dan lembaga sensor film dilihat dari penyensoran yang dilakukan dan gambar yang diambil tidak mengandung aspek pornografi.

Kesimpulan dari tayangan reportase investigasi episode "ayam kampus" yang ditinjau dari penerapan etika jurnalistik yang dilakukan wartawan sudah berpedoman pada kode etik jurnalistik walaupun masih ada yang tidak sesuai dengan kode etik yang berlaku namun keputusan dan tindakan yang diambil harus didasarkan pada beberapa alasan.

\section{SIMPULAN}

Berdasarkan hasil analisis, disimpulkanbahwa: Program Acara Reportase Investigasi Di TRANS TV Episode "Ayam Kampus" beberapa sudah berpedoman pada etika jurnalistik dilihat dari kode etik jurnalistik. Namun ada satu yang belum sesuai pada etika jurnalistik yaitu pengambilan berita terhadap narasumber belum sesuai dengan pasal 2, dimana wartawan tidak menempuh cara-cara yang profesional dalam melaksanakan tugas 
jurnalistik, karena disini wartawan membayar nasasumber atau pelaku kejahatan untuk memperoleh informasi.

Sebuah penilaian dibuat dan tindakan yang diambil untuk keputusan harus didasarkan pada beberapa alasan yang terdiri dari empat langkah, yaitu fakta, nilai, prinsip dasar, dan loyalitas. Pada tahap prinsip peneliti menemukan bahwa keputusan yang diambil oleh tim Reportase Investigasi adalah merupakan keputusan yang diambil berdasarkan prinsip hedonisme.

Tetapi memperjuangkan kesenangan pribadi tanpa memikirkan apa yang didapatkan oleh orang lain bukan hal yang relevan pada kehidupan sosial saat ini. Hedonisme ada pada masa 433-455 SM sedangkan ilmu pengetahuan telah berkembang dengan berbagai aturan yang mempengaruhinya. Jadi tim Reportase Investigasi Trans TV memilih hedonisme sebagai prinsip dasar yang melandasi kegiatan jurnalisme mereka.

\section{DAFTAR PUSTAKA}

Buku:

Arikunto, S. 2010. Prosedur Penelitian. Jakarta: Rineka Cipta.

Fink, C. Conrad. 1995. Media Ethics. Massachusseetts: Allyn \& Bacon.

Moleong. 2008. Metodologi Penelitian Kualitatif. Bandung: PT. Remaja Rosdakarya.

Mufid, Muhammad.2010. Etika dan Filsafat Komunikasi. Jakarta: Kencana Media

Patterson, Philip \& Lee Walkins. 2008. Media Etchis: Issue \& Cases. $7^{\text {th }}$ Ed. Boston: McGraw-Hill.
Santana, K. Septiawan. 2009. Jurnalisme Investigasi. Jakarta: Yayasan Obor Indonesia.

Online:

http://www.transtv.co.id. Profil dan Sejarah Trans $T V$. Diakses pada tanggal 15 Mei 2014.

http://www.youtube.com/watch?v=P4e47hF

$\mathrm{k} 0$. Reportase Investigasiepisode

"Ayam Kampus" 2013.Diakses pada tanggal21 Mei 2014.

http://kpid/printNews.php?newsid=88isprint $=1$. Pemenang Penghargaan KPI Awards 2010.Web Komisi Penyiaran Indonesia, diakses pada tanggal26Mei 2014.

http://jurnalteknologipendidikan.tp.ac.id.Meyaki nkan Validitas Data Melalui Triangulasi Pada Penelitian Kualitatif. Jurnal Teknologi Pendidikan, Universitas Negeri Surabaya. Diakses pada tanggal 30 Mei 2014.

http://www.bahasa.kompasiana.com/2012/02/25/ reportase-investigasi438080.html.Reportase Investigatif.Sianturi, Arini. 2012. Diakses pada tanggal 15 Agutus 2014.

http://www.hendralesmana.com/ayamkampus-cantik.wp\#. Ayam Kampus. Lesmana, Hendra. 2010. Diakses pada tanggal 20 Agustus 2014. 